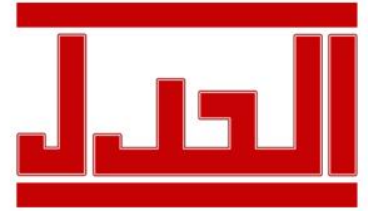

ISSN: $1979-4940$

E-ISSN : 2477-0124
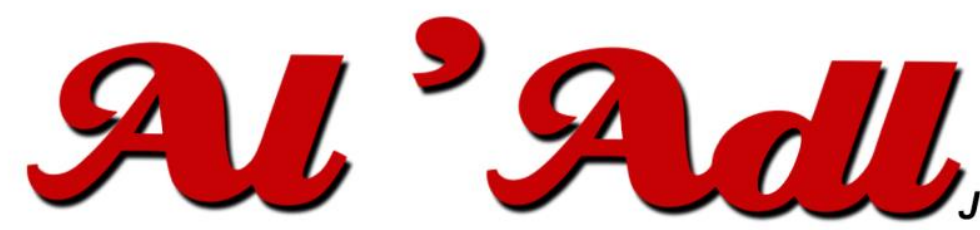

Jurnal Hukum

Editorial Office: Faculty of Law, Islamic University Of Kalimantan,

Jalan Adhyaksa No. 2 Kayutangi Banjarmasin, Kalimantan Selatan, Indonesia (70123)

Email:al_adl@uniska-bjm.ac.id

Web: http://ojs.uniska-bjm.ac.id

\title{
STATUTA PSSI DALAM HIERARKI PERATURAN PERUNDANG-UNDANGAN DI INDONESIA
}

\author{
Muhammad Ajid Husain \\ Universitas Darul Ulum, Indonesia \\ Jalan Gus Dur Nomor 29A, Kabupaten Jombang, Jawa Timur \\ Email: muhammadajid.undar@gmail.com
}

\begin{abstract}
Submitted : 2 Desember 2021
Revised : 11 Desember 2021

Accepted $\quad: 17$ Desember 2021

Published : 18 Januari 2022
\end{abstract}

Jurnal Al Adl by Universitas Islam Kalimantan Muhammad Arsyad albanjari is licensed under a Creative

Commons Attribution 4.0 International License. (CC-BY)

\begin{abstract}
The legal position of the PSSI statute still has been pros and cons among legal experts and football activists in Indonesia due to two different views - the first view states that the PSSI statute is Lex Sportiva which has immunity to national law, whereas the second view considers the PSSI statute cannot override the national law applied in Indonesia. This research used a normative legal research method. Based on the research conducted, the PSSI Statute as Lex Sportiva is only a rule of the game, not a rule of the law as stated in Article 7 Paragraph (1) of the Law on the Establishment of Laws and Regulations containing the types of Laws and Regulations in Indonesia. The upcoming arrangements related to the position of the PSSI statute can be done by revising the national sport system law or issuing new laws and regulations in which regulate the division of authority between the Government and PSSI and implementing criminal sanctions regarding persecution and scoring in football matches.
\end{abstract}

Kewords: PSSI Statute; Lex Sportiva; Sports Law

\section{Abstrak}

Kedudukan hukum statuta PSSI hingga saat ini masih menjadi pro kontra di kalangan pakar hukum dan pegiat sepak bola di Indonesia. Hal ini dikarenakan adanya dua pandangan yakni pertama memandang bahwa statuta PSSI merupakan Lex Sportiva yang mempunyai imunitas terhadap hukum nasional, sedangkan pandangan kedua menganggap statuta PSSI tidak dapat mengesampingkan hukum nasional yang berlaku di Indonesia. Penelitian ini menggunakan metode penelitian hukum normatif. Berdasar penelitian yang dilakukan, Statuta PSSI sebagai Lex Sportiva hanya sebuah rule of the game dan bukan sebagai rule of the law seperti yang tercantum dalam Pasal 7 Ayat (1) Undang-Undang Pembentukan Peraturan Perundang-undangan yang berisi jenis-jenis Peraturan Perundang-undangan di Indonesia. Pengaturan ke depan terkait kedudukan statuta PSSI dapat dilakukan dengan merevisi undang-undang sistem keolahragaan nasional ataupun dengan menerbitkan peraturan perundangundangan baru yang di dalamnya mengatur pembagian kewenangan antara Pemerintah dan PSSI serta menerapkan sanksi pidana terkait penganiayaan dan pengaturan skor dalam pertandingan sepak bola.

Kata Kunci: Statuta PSSI; Lex Sportiva; Hukum Olahraga. 


\section{PENDAHULUAN}

Sepak Bola merupakan salah satu cabang olahraga yang paling banyak diminati penduduk dunia, tidak terkecuali di Indonesia. ${ }^{1}$ Muhajir memberikan pendapat mengenai pengertian dari sepak bola bahwa Permainan sepakbola dimainkan dalam dua babak $(2 \times 45$ menit) dengan waktu istirahat 15 menit diantara dua babak tersebut. Permainan sepak bola adalah permainan beregu yang dimainkan masing-masing 11 orang, termasuk seorang penjaga gawang. Tujuan permainan ini adalah untuk memenangkan pertandingan dengan cara memasukkan bola sebanyak-banyaknya ke gawang lawan dan mempertahankan gawangnya sendiri agar terhindar dari kemasukan bola dari serangan lawan. Suatu kesebelasan sebagai pemenang apabila kesebelasan tersebut dapat memasukkan bola ke gawang lebih banyak dan kemasukan bola lebih sedikit jika dibandingkan dengan lawannya. ${ }^{2}$

Awal sejarah dari lahirnya sepak bola sendiri sampai sekarang menjadi sebuah perdebatan. Banyak yang mengatakan bahwa sepak bola lahir dari dataran Eropa sedang beberapa yang lain menyatakan bahwa sepak bola lahir dan berkembang dari dataran cina dan jepang yang kemudian diikuti oleh italia pada abad ke-16. ${ }^{3}$ FIFA sebagai organisasi tertinggi dari persepak bolaan dunia menyatakan bahwa sepak bola lahir dari permainan yang dilakukan masyarakat Cina diantara abad ke-2 sampai dengan abad ke-3 SM di dataran China, masyarakat Cina sendiri lebih mengenal permainan sepak bola saat itu dengan sebutan Tsu Chu. Di Indonesia, terdapat organisasi sepakbola yang berada di bawah naungan FIFA yaitu PSSI. PSSI merupakan badan yang membawahi segala aktifitas sepak bola di Indonesia. Mulai dari Tim Nasional, kompetisi, hingga pembinaan sepak bola di Indonesia merupakan tanggungjawab PSSI sebagai Induk dari persepak bolaan Indonesia.

Perjalanan PSSI dalam mengawal persepak bolaan Indonesia tidak melulu berjalan mulus. Permasalahan dalam berbagai bidang di dalam PSSI seringkali mengiringi perjalanan dari PSSI sendiri. Salah satu permasalahan yang muncul yaitu ketika PSSI menggelar sebuah Turnamen ataupun Kompetisi baik di kelas usia muda ataupun dalam jenjang senior, permasalah tersebut antara lain seringnya terjadi kekerasan baik berupa penganiayaan atau

\footnotetext{
${ }^{1}$ Bayan Ardana Wikarta \& Muzni Rofik, (2020) "Latihan Small Sided Games Dalam Ketepatan Passing Pada Ekstrakurikuler Sepak Bola", JURNAL SPORTIF Pendidikan Jasmani, Kesehatan dan Rekreasi, Volume 5 Nomor 2, hlm. 1.

2 Pedomanta Keliat dan Boby Helmi, (2018), "Upaya Meningkatkan Hasil Belajar Shooting Pada Permainan Sepak Bola Melalui Gaya Mengajar Inklusi Pada Siswa Kelas Viii Smp Negeri 4 Percut Sei Tuan", Jurnal Ilmiah STOK Bina Guna Medan, Volume 6 Nomor 2, hlm. 49.

${ }^{3}$ Mikanda Rahmani, (2014). Buku Super Lengkap Olahraga. Jakarta: Dunia Cerdas, hlm. 9.
} 
bahkan peristiwa yang menyebabkan hilangnya nyawa dalam sebuah pertandingan sepak bola. Kejadian-kejadian tersebut seringkali terjadi dalam persepak bolaan di Indonesia dan melibatkan elemen-elemen dalam sebuah pertandingan tersebut.

Sebenarnya berkaitan dengan kasus-kasus yang terjadi dalam pertandingan sepak bola di bawah naungan PSSI tersebut bukannya tanpa sanksi yang jelas. PSSI sendiri mempunyai Peraturan Umum Pertandingan yang merupakan dasar diberlakukannya sanksi jika terjadi kejadian seperti kekerasan dalam lapangan. Mengenai sanksi tersebut diatur lebih jelas dalam Pasal 55 Peraturan umum pertandingan PSSI.

Penerapan sanksi-sanksi dari PSSI sendiri bukannya tanpa pro-kontra. Sanksi-sanksi yang disediakan oleh PSSI, baik yang tertera dalam Peraturan Umum Pertandingan maupun Kode Disiplin, terkait penganiayaan maupun pengaturan skor dalam kompetisi sepak bola Indonesia nyatanya tidak bisa sepenuhnya menjadi solusi atas maraknya penganiayaan dan juga pengaturan skor di Indonesia. Banyak kasus yang berkaitan dengan penganiayaan ataupun pengaturan skor dalam sebuah pertandingan bahkan tidak diberikan hukuman sama sekali oleh Komisi Disiplin PSSI yang merupakan pengadilan bagi elemen-elemen yang terlibat dalam kekerasan dalam sebuah pertandingan sepak bola.

Selain pro kontra mengenai hal tersebut diatas, terjeadi perdebatan pula mengenai penerapan hukum nasional dalam penyelenggaraan sepak bola di Indonesia. Pro-kontra penerapan hukum nasional disebabkan oleh dua alasan. Pertama memandang negara terlalu jauh ikut campur dalam hukum olahraga khususnya sepak bola. Sedang pandangan kedua menganggap penerapan hukum nasional diperlukan karena penyelenggaraan sepak bola di Indonesia yang kurang baik, dan juga banyaknya kasus-kasus yang dapat dikenakan sanksi pidana.

Perbedaan dua pandangan tersebut pada dasarnya terjadi antara PSSI sebagai penyelenggara sepak bola yang mewakili pandangan pertama tentang Lex Sportiva sebagai Lex Specialis dengan Pemerintah sebagai penyelenggara Negara yang mewakili pandangan kedua tentang Lex Sportiva yang bukan merupakan Lex Specialis. PSSI sebagai induk dari sepak bola Indonesia memandang bahwa permasalahan hukum yang terjadi dalam ranah sepak bola merupakan wewenang dari hukum olahraga atau lazim disebut sebagai Lex Sportiva dan bukan wilayah dari hukum nasional, tetapi Pemerintah menganggap bahwa segala permasalahan hukum yang terjadi di wilayah negara Indonesia merupakan tanggung jawab mereka sebagai wujud dari kedaulatan dari sebuah negara. 
Perbedaan pandangan terkait sejauh mana hukum nasional dapat memasuki ranah hukum olahraga dan juga persinggungan yang terjadi antara hukum nasional dengan hukum olahraga atau dalam hal ini statuta FIFA dan Statuta PSSI dengan hukum nasional sangat menarik untuk dikaji. Tidak adanya kejelasan hukum berkaitan dengan permasalahan hukum yang berada di lingkup olahraga khususnya sepak bola memunculkan pertanyaan tentang bagaimana sebenarnya kedudukan hukum olahraga atau dalam hal ini statuta FIFA dan PSSI dalam sistem hukum di Indonesia.

\section{RUMUSAN MASALAH}

Berdasarkan latar belakang tersebut di atas, Penulis menarik dua permasalahan yang kemudian dijadikan fokus dari penelitian ini, yakni mengenai bagaimana kedudukan hukum statuta pssi dalam hierarki peraturan perundang-undangan di indonesia dan bagaimana pengaturan ke depan terkait kedudukan statuta PSSI sebagai Lex Sportiva dalam Negara hukum Indonesia

\section{METODE PENELITIAN}

Ilmu hukum akan mempunyai kewibawaan dan kekuatannya apabila bersifat integral dalam aspek ontologis, epistemologis, dan aksiologis. Oleh sebab itu diperlukan metodemetode dalam menemukan hukum. ${ }^{4}$ Dalam penelitian ini sendiri Penulis menggunakan metode penelitian Hukum Normatif. Penelitian Hukum Normatif menurut Soerjono Soekanto cenderung mencitrakan hukum sebagai disiplin preskriptif yang mana hanya melihat hukum hanya dari sudut pandang norma-normanya saja. ${ }^{5}$ Metode pendekatan yang penulis gunakan adalah pendekatan perundang-undangan (statute approach), pendekatan konseptual (conceptual approach) dan pendekatan kasus (case approach). Metode analisis bahan hukum di penelitian ini menggunakan metode analisis preskriptif.

Bahan hukum yang digunakan adalah berupa bahan hukum primer. Bahan hukum primer bersumber pada peraturan perundang-undangan yang ada kaitannya dengan permasalahan sebagaimana dipaparkan dalam penelitian ini. Bahan hukum primer yang digunakan sebagai berikut:

\footnotetext{
${ }^{4}$ Yati Nurhayati, (2013), "Perdebatan Metode Normatif dengan Metode Empirik Dalam Penelitian Ilmu Hukum Ditinjau Dari Karakter, Fungsi dan Tujuan Ilmu Hukum”, Jurnal Al Adl, Volume 5 Nomor 10, hlm. 15.

5 Depri Liber Sonata, (2014), "Metode Penelitian Hukum Normatif dan Empiris", Fiat Justicia Jurnal Ilmu Hukum, Volume 8 Nomor 1, hlm. 25.
} 
a. Undang-Undang Nomor 12 Tahun 2011 tentang Pembentukan Peraturan Perundangundangan.

b. Undang-Undang Nomor 3 Tahun 2005 tentang Sistem Keolahragaan Nasional.

c. Putusan Pengadilan Negeri Surakarta Nomor 319/Pid.B/2009/PN.Ska dan Nomor 381/Pid.B/PN.Ska.

d. Neutral Citation Number: [2004] EWCA Crim 3246 in The Supreme Court of Judicature Court of Appeal (Criminal Appeals Division) on Appeal from The Crown Court at Canterbury.

e. Statuta FIFA.

f. Statuta PSSI.

Bahan hukum sekunder meliputi semua jenis publikasi berupa hukum yang bukan merupakan dokumen-dokumen resmi. Publikasi tentang hukum seperti buku-buku teks, kamus-kamus hukum, jurnal hukum.

\section{PEMBAHASAN}

\section{Kedudukan Hukum Statuta PSSI Dalam Hierarki Peraturan Perundang-Undangan Di Indonesia}

Perkembangan olahraga yang pesat, khususnya sepak bola dilihat oleh penulis tidak sejalan dengan perkembangan dari kajian mengenai hukum olahraga yang mengatur segala aspek hukum dalam kegiatan olahraganya. Penulis memandang masih simpang siurnya kedudukan hukum olahraga merupakan suatu problem tersendiri yang dirasa cukup rumit. Hingga kini, masih terdapat dua pandangan besar yang mengikuti perkembangan hukum olahraga.

Pertama, pandangan yang lazim menyebut hukum olahraga sebagai Lex Sportiva. Kelompok pertama ini merupakan penganut madzab domestic sports law atau Global Sports Law. Pandangan pertama ini dengan tokohnya yang terkenal yakni Ken Foster, memandang secara garis besar bahwa hukum olahraga atau Lex Sportiva sebagai hukum yang tidak berada di dalam hukum internasional maupun hukum nasional, melainkan ia berdiri sendiri sebagai hukum transnasional yang berdiri sendiri dan tidak terikat oleh hukum lainnya.

Kedua, pandangan National Sports Law dan International Sports Law. Kelompok ini dengan salah satu tokohnya yang bernama Mark James, memandang bahwa hukum olahraga merupakan pengembangan dari kerangka hukum dan prinsip-prinsip hukum yang diterapkan langsung kepada bidang olahraga oleh parlemen dan peradilan. Dengan kata lain, National Sports Law merupakan undang-undang yang dihasilkan parlemen dan putusan-putusan 
pengadilan yang berpengaruh terhadap pemerintahan, administrasi, konsumsi dan bahkan partisipasi dalam olahraga; ini merupakan penerapan hukum yang sebenarnya ke dalam olahraga. ${ }^{6}$ Mark James mendefinisikan National Sports Law sebagai hukum yang diciptakan oleh parlemen, pengadilan, dam dilaksanakan oleh pihak-pihak yang berkaitan dengan regulasi dan pemerintahan dalam olahraga yang kemudian dikembangkan untuk menyelesaikan sengketa olahraga. ${ }^{7}$

Secara sederhana Lex Sportiva dapat dirumuskan sebagai hukum yang khusus mengatur tentang olahraga yang dibentuk oleh institusi komunitas olahraga itu sendiri dan berlaku serta ditegakkan oleh lembaga olahraga itu sendiri tanpa intervensi dari hukum positip suatu negara dan tanpa intervensi dari hukum internasional. Dimitrios Panagiotopoulos menyatakan bahwa,

“... Lex Sportiva is a legal order, which incorporates state-adopted law and the law adopted by the national and International bodies representing organized sport. These bodies operate to the standards of unions and in the context of the autonomy granted to such bodies and operate within states in a pyramid-like fashion and at International level in the form of a special relationship linking them to the relevant International sports federation. The law produced in this manner is thus a law which is, in essence, non-national law, which claims for itself direct and preferential application within sports legal orders and the par excellence law in sports life.",

Menurut Franck Latty, selain F Rigaux yang menggunakan ungkapan latin Lex Sportiva dalam meneliti aspek hukum olahraga, Th. Summerer juga telah melakukan studi dimana ia mengualifikasikan anggaran dasar organisasi-organisasi olahraga internasional sebagai Lex Sportiva Internationalis sui generis. ${ }^{9}$ Franck Latty membedakan munculnya hukum olahraga internasional yang otonom yang berbeda dari hukum negara dan yang melampaui pembagian dunia ke dalam sistem-sistem hukum yang berdaulat, meskipun terdapat Lex Sportiva internasional yang terbentuk oleh sistem hukum olahraga transnasional. Ungkapan dan istilah Lex Sportiva secara mudah dapat ditemui dalam yurisprudensi Court of Arbitration for Sport (CAS). Sejak didirikan sebagai perpanjangan tangan dari IOC pada tahun 1984, CAS telah berkembang menjadi otoritas yang dihormati dalam penyelesaian

\footnotetext{
${ }^{6}$ Mark James, (2010), Sports Law, Hampshire: Palgrave Macmilan, hlm. 8.

${ }^{7}$ Ibid.

8 Jevon Andriani Djayadilaga \& Arinto Nugroho, (2021), Perlindungan Hukum Terhadap Pemain Sepakbola Profesional Di Indonesia Yang Mengalami Keterlambatan Dalam Pembayaran Upah, Novum: Jurnal Hukum, Volume 8 No 4, hlm. 7.

${ }^{9}$ Hinca IP Pandjaitan XII, (2011), Kedaulatan Negara vs Kedaulatan FIFA, Jakarta: Gramedia Pustaka Utama, hlm. 145.
} 
sengketa yang berhubungan dengan berbagai macam olahraga dan mengeluarkan berbagai macam yurisprudensi dalam penyelesaian sengketa tersebut. Tidak seperti pengadilan sipil tradisional, CAS memperoleh yurisdiksinya dalam kasus tertentu hanya melalui kesepakatan bersama dari pihak yang terlibat. Prosedur ini, yang dikenal sebagai arbitrase, dirancang untuk mengikat semua pihak. Dalam pelaksanaan tugasnya, CAS dapat menjadi sumber kategori baru norma-norma yang menggabungkan peraturan-peraturan yang sesuai untuk kompetisikompetisi dan prinsip-prinsip dasar hukum. ${ }^{10}$

Terkait perdebatan mengenai kedudukannya, Franck Latty menggambarkan kedudukan Lex Sportiva tidak berada dalam sistem hukum nasional dan juga tidak berada di dalam sistem hukum internasional, melainkan berada di dalam sistem hukum transnasional. ${ }^{11}$ Hinca Pandjaitan dalam bukunya juga menyampaikan pendapat yang sama, ia menggambarkan dalam sebuah contoh kasus dalam mekanisme penegakan hukum disiplin terhadap kompetisi sepak bola profesional, salah satu sanksi adalah sanksi larangan menggunakan stadion tertentu dikarenakan keributan dan kerusuhan pendukung tuan rumah yang dianggap sebagai kegagalan panitia pelaksana pertandingan kompetisi sepak bola berdasarkan Kode Disiplin FIFA. Contoh kasus tersebut merupakan contoh kasus umum yang sering terjadi termasuk di Indonesia. Komisi disiplin PSSI juga menjatuhkan hukuman yang serupa terhadap pelanggaran yang sama di dalam kompetisi sepak bola di bawah yurisdiksinya sebagai badan peradilan berdasarkan kode disiplin PSSI yang sejalan dengan Kode Disiplin FIFA ${ }^{\cdot 12}$

Pandangan lain mengenai kedudukan dari Lex Sportiva disampaikan oleh J. Nafizer dan M. Bellof, keduanya memandang bahwa Lex Sportiva sebagai bagian dari hukum internasional. J. Nafziger berpendapat bahwa “... as an authoritative process of decision making and legal discipline, International Sports Law is as much matter of International law as of sports law. Dalam pendapatnya Nafziger secara tegas menyatakan jika hukum olahraga International sebagai cabang dari hukum internasional. Ia mengemukakan bahwa salah satu aspek pokok dari hukum olahraga adalah jus commune, yakni prinsip umum hukum internasional. ${ }^{13}$ M. Bellof memandang bahwa Lex Sportiva merupakan hukum olahraga yang mempunyai karakter internasional yang bersifat inheren karena landasan normatifnya terdapat

\section{${ }^{10}$ Ibid., hlm. 146}

${ }^{11}$ Aruan, P., Bintang, H., Sirait, N. N., \& Leviza, J., (2014), Berlakunya Statuta Fédération Internationale De Football Association (Fifa) Dikaitkan Dengan Kedaulatan Negara (Studi Kasus Dualisme Persatuan Sepakbola Seluruh Indonesia (Pssi)), Journal of USU International Law, Volume 2 No 1.

${ }^{12}$ Hinca Pandjaitan, Op.Cit., hlm. 136-137

${ }^{13}$ Ibid., hlm. 154 
dalam konstitusi federasi-federasi olahraga internasional dan memiliki tiga elemen pokok, yaitu:

- It has a transnational norms generated by the rules and practice of inter-national sporting federations

- It has unique jurisprudence, with legal prinsiples that are different from those of national courts, and which is declarated by the court of arbitration of sports; and

- It is constitutionally autonomous from national law ${ }^{14}$

Menurut M. Beloff, hukum olahraga internasional tidak sekedar menggabungkan norma-norma Negara. Hukum ini menyiratkan adanya badan hukum khusus. Hukum olahraga internasional menghasilkan prinsip sui generis yang tidak terdapat dalam hukum lain. Sumber hukum olahraga internasional adalah hukum internasional publik. Prinsip doctrinal dan konseptual hukum olahraga internasional tidak dapat dikembangkan sepenuhnya kecuali oleh lembaga terpisah. Tanpa pengadilan olahraga internasional, bisa jadi tidak ada yurisprudensi khusus, dan tanpa yurisprudensi khusus, tidak ada hukum organisasi olahraga yang real. Jadi, pengakuan terhadap CAS sebagai sumber kelembagaan pokok bagi hukum olahraga internasional merupakan aspek kunci. Grundnorm, untuk hukum olahraga internasional merupakan otonomi untuk proses pengambilan keputusan oleh federasi olahraga internasional.

Pendapat mengenai kedudukan Lex Sportiva sebagai bagian hukum internasional ditolak oleh Ken Foster, ia membuat rumusan bahwa Lex Sportiva merupakan a Global Sports Law sebagai sebuah peraturan hukum yang otonom dan independen, yang melintasi wilayah hukum Negara, yang diciptakan oleh lembaga swasta global, yang mengatur olahraga secara independen. Ken Foster memandang karakteristik utama dari hukum olahraga global adalah peraturan kontraktual, dengan kekuatan mengikatnya didasarkan pada perjanjian untuk menyerahkan kekuasaan dan hak kepada otoritas dan yurisdiksi federasi olahraga internasional tersebut. Selaim itu, Lex Sportiva as a Global Sports Law tidak diatur oleh hukum nasional. $^{15}$

Pendapat Ken Foster didukung oleh pandangan dari G. Teubner dalam bukunya "A Global law without a state”. Ia memandang Lex Sportiva sebagai sui generis sebagai seperangkat prinsip yang diciptakan dari norma-norma hukum lintas Negara yang dihasilkan

\footnotetext{
14 Ken Foster, Is There a Global Sports Law?, https://www.researchgate.net/publication/251276514_Is_There_a_Global_Sports_Law, (diakses pada November 2021).

${ }^{15}$ Foster K., (2019). Global Sports Law Revisited, Entertainment and Sports Law Journal, 17: 4. DOI: https://doi.org/10.16997/eslj.228, hlm. 1-14.
} 
oleh peraturan, dan penafsiran terhadap peraturan tersebut dilakukan oleh federasi-federasi olahraga internasional. Lex Sportiva as a Global Sports Law merupakan peraturan hukum terpisah yang secara global bersifat otonom dan independen. Hal ini menggambarkan jika federasi olahraga tidak dapat diatur oleh pengadilan Negara. Mereka hanya dapat diatur oleh lembaga-lembaga internal mereka sendiri atau oleh lembaga-lembaga eksternal yang dibuat atau disahkan oleh mereka. ${ }^{16}$

Norma-norma tersebut yang berlaku terhadap seluruh komunitas olahraga dan pada pokoknya terhadap kelompok-kelompok olahraga internasional, patut menyandang nama Lex Sportiva. Penggunaan arbitrasi memungkinkan untuk mengangkat prinsip-prinsip umum yang sesuai dengan kebutuhan-kebutuhan kepentingan yang hendak diatur oleh prinsip-prinsip tersebut. Prinsip-prinsip ini bersifat otonom dalam arti bahwa prinsip-prinsip tersebut tidak ditarik dari suatu sistem hukum negara dimana situasi sengketa dibatasi. Dengan inspirasi yang sama, banyak pakar yang mengualifikasikan prinsip-prinsip yang diambil oleh yurisprudensi CAS, bahkan seluruh yurisprudensinya sebagai Lex Sportiva. A. Rigozzi, memberikan pengertian tentang Lex Sportiva sebagai serangkaian norma hukum privat yang diambil dari interaksi antara norma-norma hukum olahraga dan prinsip-prinsip umum yang sesuai dengan sistem-sistem hukum negara, sebagaimana diwujudkan dalam arbitrasearbitrase olahraga. ${ }^{17}$

Pandangan kedua yakni National Sports Law dan International Sports Law, Mark James berpendapat bahwa National Sports Law merupakan hukum yang diciptakan oleh parlemen, pengadilan dan dilaksanakan oleh pihak-pihak yang berkaitan dengan dengan regulasi dan pemerintahan dalam olahraga yang kemudian dikembangkan untuk menyelesaikan sengketa olahraga. Seperti misalnya di Prancis terdapat Loi du Sport (Loi No. 84-610 du 16-07-1984) yang mengatur secara khusus berbagai aspek olahraga. Sumber lain terkait dengan National Sport law terdapat dalam putusan pengadilan inggris. Putusan pengadilan ini muncul dikarenakan memang tidak adanya undang-undang di Inggris yang secara khusus mengatur mengenai jalannya olahraga. Lalu, bagaimana dengan Indonesia sendiri?

Perkembangan National Sports Law di Indonesia ditandai dengan adanya peraturan perundang-undangan yang khusus mengatur mengenai jalannya olahraga, yakni Undangundang Nomor 3 Tahun 2005 tentang Sistem Keolahragaan Nasional serta Peraturan

\footnotetext{
${ }^{16}$ G. Teubner (Ed.), (1997), Global Law Without a State, Dartmouth: Andover, hlm. 23.

${ }^{17}$ A. Rigozzi, sebagaimana dikutip oleh Hinca Pandjaitan, Op.Cit., hlm. 147.
} 
Pemerintah Nomor 16 Tahun 2007 tentang Penyelenggaraan Keolahragaan. Kedua peraturan perundang-undangan tersebut mengatur segala aspek yang terkait dengan bidang keolahragaan. Kedua peraturan perundang-undangan tersebut, baik Undang-Undang Nomor 3 Tahun 2005 tentang Sistem keolahragaan Nasional dan Peraturan Pemerintah Nomor 16 Thaun 2007 tentang Penyelenggaraan Keolahragaan dapat dikatakan sebagai bagian dari instrument National Sports Law.

Instrumen lain National Sports Law yang terdapat di Indonesia yakni putusan Pengadilan Negeri Surakarta Nomor 319/Pid.B/2009/PN.Ska yang dilanjutkan ke tingkat banding pada Pengadilan Tinggi Semarang dengan Nomor 173/Pid/2010/PT.Smg dengan terdakwa Nova Zaenal Mutaqin dan putusan Pengadilan Negeri Surakarta Nomor 381/Pid.B/2009/PT.Ska yang juga dilanjtukan ke tingkat banding pada Pengadilan Tinggi Semarang dengan Nomor 190/Pid/2010/PT.Smg dengan terdakwa Bernard Momadao. Putusan tersebut merupakan buntut terjadinya perkelahian antara kedua pemain tersebut dalam lanjutan pertandingan sepak bola Divisi Utama Liga Indonesia yang mempertemukan Persis Solo dengan Gresuk United di Stadion R. Maladi, Solo pada tanggal 12 Februari 2009. Pada putusan tersebut majelis hakim menyatakan bahwa aturan yang dibuat oleh PSSI sebagai induk sepak bola hanya merupakan rule of the game di dalam permainan sepak bola, dan bukan merupakan rule of the law yang terdapat dalam undang-undang Nomor 10 Tahun 2004 tentang Pembentukan Peraturan Perundang-undangan segingga rule of the game tersebut dianggap tidak dapat mengesampingkan rule of the law yang ada.

Dua pandangan tersebut pada akhirnya memunculkan pertanyaan mendasar terkait kedudukan dari statuta PSSI dalam sistem hukum Indonesia. Apakah ia berdiri secara otonom seperti pandangan dari para penganut domestic sports law dan Global Sports Law, atau justru ia tunduk terhadap hukum nasional?

Para tokoh penganut Lex Sportiva memandang berlakunya asas lex specialis derogate lex generali sebagai dasar untuk mengesampingkan peraturan perundang-undangan lain yang berada di dalam sistem hukum Indonesia. Akan tetapi, penulis memandang bahwa Lex Sportiva sendiri atau dalam hal ini Statuta PSSI tidak berada di dalam hierarki peraturan perundang-undangan dalam sistem hukum Indonesia. Terkait hierarki tersebut, terdapat teori perundang-undanga yang dikembangkangkan oleh murid Hans Kelsen, yakni Nawiasky yang 
disebut dengan theorie von stufenufbau der rechtsordnung. Menurut A. Hamid S. Attamimi, Nawiasky menjabarkan susunan norma sebagai berikut: ${ }^{18}$

1. Norma fundamental negara (Staatsfundamentalnorm);

2. Aturan dasar negara (Staatsgrundgesetz);

3. Undang-Undang formal (Formell Gesetz);

4. Peraturan pelaksanaan dan peraturan otonom (Verordnung En Autonome Satzung).

Staatsfundamentalnorm adalah norma yang merupakan dasar bagi pembentukan konstitusi atau Undang-Undang Dasar (staatsverfassung) dari suatu negara. Menurut Nawiasky, norma tertinggi yang oleh Hans Kelsen disebut sebagai norma dasar (basic norm) dalam suatu negara sebaiknya tidak disebut sebagai staatsgrundnorm melainkan Staatsfundamentalnorm, atau norma fundamental negara. Grundnorm pada dasarnya tidak berubah-ubah, sedangkan norma tertinggi berubah misalnya dengan cara kudeta atau revolusi. ${ }^{19}$

A. Hamid S. Attamimi kemudian membandingkan teori dari Hans Nawiasky itu dengan teori Hans Kelsen dan menerapkannya pada struktur tata hukum di Indonesia dan mengemukakan suatu struktur tata hukum Indonesia, sebagai berikut:

1. Staatsfundamentalnorm: Pancasila (Pembukaan UUD 1945).

2. Staatsgrundgesetz: Batang Tubuh UUD 1945, Tap MPR, dan Konvensi

3. Ketatanegaraan.

4. Formell gesetz: Undang-Undang.

5. Verordnung en Autonome Satzung: Secara hierarkis mulai dari Peraturan Pemerintah hingga Keputusan Bupati atau Walikota. ${ }^{20}$

Gagasan A. Hamid Attamimi ini menjadi dasar pijakan dalam melihat tata urutan peraturan perundang-undangan Indonesia hingga kini. Gagasan ini pula yang diadopsi ke dalam UU 10/2004 maupun UU 12/2011, yang tercantum dalam Pasal 7 Ayat (1) Undangundang Nomor 12 Tahun 2011 tentang Pembentukan Peraturan Perundang-undangan, jenisjenis peraturan perundang-undangan yaitu terdiri atas:

a. Undang-Undang Dasar Negara Republik Indonesia Tahun 1945;

b. Ketetapan Majelis Permusyawaratan Rakyat;

c. Undang-Undang/Peraturan Pemerintah Pengganti Undang-Undang;

d. Peraturan Pemerintah;

e. Peraturan Presiden;

18 Bivitri Susanti, (2017), Menyoal Jenis Dan Hierarki Peraturan Perundang-Undangan Di Indonesia, JURNAL JENTERA, Volume 1 Nomor 2, hlm. 130.

19 Ibid.

${ }^{20}$ Ibid. 
f. Peraturan Daerah Provinsi; dan

g. Peraturan Daerah Kabupaten/Kota.

Dalam jenis-jenis peraturan perundang-undangan yang disebutkan oleh Pasal 7 Ayat (1) Undang-undang nomor 12 Tahun 2011 tentang Pembentukan Peraturan Perundangundangan tersebut tidak menyatakan Statuta Organisasi Olahraga sebagai bagian dari jenisjenis peraturan perundangan. Sehingga, penulis memandang bahwa Statuta PSSI hanyalah sebatas rule of the game yang tidak dapat mengesampingkan kedudukan dari rule of the law yakni hukum positif yang terdapat dalam sistem hukum Indonesia. Hal tersebut disebabkan Statuta olahraga dalam hal ini Statuta PSSI tidak disebutkan sebagai salah satu jenis-jenis peraturan perundang-undangan.

Selain itu, Maria Farida menjelaskan bahwa dalam sistem perundang-undangan di Indonesia hanya dikenal satu nama jenis undang-undang, yaitu keputusan yang dibentuk oleh Dewan Perwakilan Rakyat (DPR), dengan persetujuan bersama Presiden, dan disahkan oleh Presiden. Tidak ada Undang-Undang yang dibentuk oleh lembaga lainnya baik di pusat maupun di daerah, sehingga di Indonesia tidak ada istilah Undang-Undang Pusat ataupun Undang-Undang Lokal. ${ }^{21}$ Pasal 20 Ayat (2) UUD NRI 1945 menyatakan bahwa, "Setiap rancangan undang-undang dibahas oleh Dewan Perwakilan Rakyat dan Presiden untuk mendapat persetujuan bersama”. Bukan tanpa sebab mengapa pembentukan undang-undang harus mendapatkan persetujuan DPR. Tidak lain karena DPR yang merupakan lembaga legislatif yang merupakan representasi dari rakyat Indonesia yang memiliki fungsi legislasi diamanatkan oleh Pasal 20 Ayat (1) UUD NRI 1945 yaitu, "Dewan Perwakilan Rakyat memegang kekuasaan membentuk undang undang." Sehingga setiap pembentukan UndangUndang harus melalui DPR sebagai lembaga legislatif yang diberi kewenangan dalam membentuk undang-undang. ${ }^{22}$

Penjabaran tersebut menunjukkan bahwa Statuta PSSI bukan merupakan undangundang, karena bukan merupakan keputusan yang dibentuk oleh Dewan Perwakilan Rakyat (DPR), dengan persetujuan bersama Presiden, dan disahkan oleh Presiden. Statuta PSSI sendiri merupakan produk yang dihasilkan oleh Kongres PSSI, dan bukan merupakan produk yang dihasilkan oleh DPR maupun Presiden. Statuta PSSI sendiri merupakan usulan yang disampaikan oleh Delegasi yang mewakili Anggota PSSI didukung secara tertulis oleh

\footnotetext{
${ }^{21}$ Muhammad Fadli, (2018), Pembentukan Undang-Undang Yang Mengikuti Perkembangan Masyarakat, Jurnal Legislasi Indonesia, Volume 15 Nomor 1, hlm. 51.

${ }^{22}$ Ibid.
} 
sekurang-kurangnya 2 (dua) Delegasi lain yang mewakili Anggota PSSI dan disetujui oleh 3/4 (tiga perempat) dari keseluruhan Delegasi yang mewakili Anggota PSSI.

Dari uraian di atas, Penulis memandang bahwa statuta PSSI sebagai Lex Sportiva tidak bisa secara serta merta membebaskan segala aspek kegiatan sepak bola professional dari ikatan hukum positif dalam sistem hukum di Indonesia. Otonomi PSSI yang tercantum dalam statutanya akan selalu diakui sebagai Lex Sportiva karena kedudukannya sebagai induk dari sepak bola professional di Indonesia. Akan tetapi, kaidah-kaidah yang terdapat dalam statuta PSSI sebagai Lex Sportiva tersebut tetap harus tunduk terhadap segala kaidah yang terdapat dalam sistem hukum di Indonesia. Hal tersebut tentunya didasari oleh kedudukan statuta PSSI yang hanya sebagai rule of the game dan bukan sebagai rule of the law seperti yang tercantum dalam Pasal 7 Ayat (1) undang-undang pembentukan peraturan perundang-undangan yang berisi jenis-jenis peraturan perundang-undangan di Indonesia serta bukan merupakan produk hukum yang dihasilkan oleh Presiden maupun DPR.

\section{Pengaturan Ke Depan Terkait Kedudukan Statuta PSSI Sebagai Lex Sportiva Peraturan Perundang-undangan di Indonesia}

Benturan kewenangan yang terjadi antara statuta PSSI beserta peraturan turunannya dengan Peraturan perundang-undangan dalam sistem hukum di Indonesia telah menyebabkan berbagai pernasalahan hingga kini. Penulis melihat terdapat beberapa permasalahan besar terkait benturan kewenangan tersebut yang sempat muncul, antara lain terkait dengan penganiayaan di dalam pertandingan, intervensi Negara ketika terjadi dualisme PSSI, serta yang akhir-akhir ini ramai menjadi pembicaraan yakni terkait pengaturan skor. Benturan kewenangan tersebut tentunya menimbulkan gangguan dalam penyelenggaraan sepak bola Profesional di Indonesia. Bahkan sempat muncul efek yang sangat buruk bagi perjalanan sepak bola professional Indonesia, yakni ketika dijatuhkannya sanksi terhadap PSSI oleh FIFA karena Negara ketika itu dianggap terlalu jauh mencampuri wewenang federasi ketika berusaha menyelesaikan masalah dualisme yang pernah terjadi.

Kewenangan intervensi oleh Negara sendiri pada dasarnya dipandang penulis sebagai perwujudan dari tujuan Negara untuk memajukan kesejahteraan umum. Adanya peraturan perundang-undangan yang mengatur mengenai sistem keolahragaan nasional merupakan bentuk keingingan Negara dalam menyejahterakan masyarakatnya melalui olahraga. Seperti dijabarkan dalam konsep welfare state, dalam suatu negara kesejahteraan (Welfare State) intevensi negara dalam sektor kehidupan masyarakat tidak dapat dihindari lagi karena negara 
dituntunt bersifat aktif dalam upaya meningkatkan kesejahteraan dan keadilan bagi masyarkat.. $^{23}$

Munculnya Undang-undang Sistem Keolahragaan Nasional pada dasarnya harus dimaknai sebagai upaya negara untuk menjalankan amanah konstitusi untuk memajukan kesejahteraan bagi seluruh warga negara Indonesia serta merupakan penjabaran dari konsep welfare state, dalam hal ini melalui olahraga. Kewenangan Pemerintah yang diberikan dalam Undang-undang Sistem Keolahragaan Nasional untuk mengatur, melaksanakan, membina, mengawasi, dan mengontrol penyelenggaraan olahraga adalah manifestasi kedaulatan Negara dan juga merupakan manifestasi dari konsep welfare state, yang dibingkai dalam sistem keolahragaan nasional dalam kerangka sistem hukum nasional Indonesia. Akan tetapi, munculnya undang-undang sistem keolahragaan nasional ini tjustru memunculkan konflik dalam sepak bola di Indonesia karena dianggap mengintervensi segala aspek dalam kegiatan persepakbolaan professional di Indonesia mengingat terdapat statuta PSSI yang juga mengatur jalannya pertandiingan sepak bola di Indonesia.

Penulis mengambil contoh menganai penganiayaan dalam pertandingan sepak bola. Penganiayaan ini sendiri sering menjadi perdebatan apakah layak dikenakan sanksi pidana atau hanya sebatas sanksi disiplin, hal ini kemudian justru menimbulkan ketidakpastian hukum. Penganiayaan, seringkali terjadi dalam pertandingan sepak bola yang melibatkan antar pemain dan bahkan pemain terhadap perangkat pertandingan. Meski kode disiplin PSSI telah mengatur mengenai sanksi dari penganiayaan di dalam lapangan, akan tetapi penulis memandang hal tersebut tidak menimbulkan efek jera. Hal tersebut dapat dilihat dari banyaknya tragedi penganiayaan yang terjadi setiap terselenggaranya sepak bola professional di Indonesia. Meski harus dipahami pula bahwa tidak semua unsur penganiayaan dalam hukum pidana dapat diaplikasikan dalam pertandingan sepak bola.

Mengenai perbuatan yang dikategorikan sebagai penganiayaan ini, harus diperhatikan terlebih dahulu mengenai karakteristik yang terdapat dalam olahraga sepak bola. Dalam sepak bola sendiri memang dimungkinkan terjadinya kontak fisik akan tetapi tidak diperkenankan terjadinya kekerasan ketika bermain. Banyak kemungkinan yang terjadi ketika kontak fisik seperti benturan, cedera (ringan/sedang/berat), bahkan bisa menyebabkan kematian. Sehingga seringkali memunculkan perdebatan mengenai berlakunya hukum pidana dalam pertandingan sepak bola.

${ }^{23}$ Rusnan, (2014), Konsep Negara Hukum Dalam Hubungan Kekuasaan Freiss Ermerssen Dalam Welfare State, Jurnal IUS, Volume II Nomor 4, hlm. 10. 
Van Hattum dan Van Bemmelen menjelaskan bahwa dalam konteks olahraga, perbuatan yang dikategorikan sebagai penganiayaan tersebut telah kehilangan karakternya sebagai perbuatan yang melanggar hukum karena adanya izin dari korban. Akan tetapi persetujuan tersebut ada batasnya, yakni tindakan kekerasan tersebut tidak boleh terlalu jauh bertentangan dari perbuatan yang dapat dibenarkan untuk dilakukan menurut cabang olahraga yang dipertandingkan. ${ }^{24}$

Senada dengan pendapat tersebut, Angelica Maure dkk dalam jurnalnya menjelaskan bahwa adanya izin pihak korban atau pihak yang sebagai dasar peniadaan pidana atau alasan penghapus pidana, sehingga terdapat beberapa perbuatan dimana sekalipun perbuatan itu telah mencocoki rumusan undang-undang tetapi pelakunya tidak dapat dipidana. Misalnya ada dua orang petinju yang saling memukul di atas ring atau arena tinju dalam suatu pertandingan yang sah, dimana mereka saling memukul dan kemungkinan besar akan saling melukai. Tetapi, sekalipun yang seorang mengalami cedera berat, lawan bertinjunya tidak dapat dijatuhi pidana karena dianggap di antara mereka telah saling memberi izin untuk dipukul, sehingga cedera yang terjadi hanya merupakan konsekuensi logis dari pertandingan tinju tersebut. $^{25}$

Senada dengan apa yang disebut di atas, Bamwell dalam pendapatnya menyatakan bahwa:

"jika seorang pemain bermain dengan mengikuti peraturan permainan dan tidak bertindak diluar aturan tersebut, hal ini menjadai rasional untuk mengatakan bahwa ia melakukan kekerasan itu dengan tidak disertai oleh kesengajaanu untuk mengakibatkan cedera pada pemain lawan dan ia tidak melakukannya dengan bisa memperkirakan bahwa tindakannya bisa mengakibatkan cedera atau kematian. Tetapi seorang pemain beniat untuk mengakibatkan cidera yang serius dan tidak memiliki simpati serta ceroboh, meskipun akhirnya cedera serius yang diharapkan timbul atau tidak, maka tindakannya merupakan tindakan yang melawan hukum." 26

Penulis mencoba mengilustrasikan pendapat dari para ahli tersebut, misalnya dalam sepak bola, pemain masih dianggap dalam batas wajar ketika merebut bola menggunakan tackling dengan maksud merebut bola dari lawannya. Hal tersebut masih dalam batas wajar dan tidak bisa dikenakan pidana, berbeda ketika seorang pemain sepak bola dengan sengaja

\footnotetext{
${ }^{24}$ P.A.F. Lamintang, (1997) Dasar-Dasar Hukum Pidana Indonesia, Bandung: Citra Aditya Bhakti, hlm. 118

${ }^{25}$ Angelica Maureen Taroreh, (2020), Izin Pihak Korban Sebagai Dasar Peniadaan Pidana Di Luar Kuhp, Jurnal Lex Crimen, Volume 9 Nomor 3, hlm. 61.

${ }^{26}$ Anderson, (2008), No License fot Thuggery: Violence, sport, and criminal law, Criminal Law Review, Volume. 7 Nomor 1, hlm. 751-763.
} 
melakukan kekerasan berupa pemukulan atau sengaja menendang lawan dengan maksud untuk menyebabkan lawannya mendapatkan luka ringan atau luka berat. Perbuatan berupa pemukulan tersebut dianggap sebagai tindakan diluar batas wajar dalam aturan sepak bola, sehingga dimungkinkan untuk dikenakan sanksi pidana atas kekerasan tersebut.

Contoh diberlakukannya sanksi pidana terhadap kekerasan di dalam pertandingan sepak bola terjadi di sebuah kompetisi sepak bola di Inggris, kasus ini lazim disebut sebagai $R v$ Barnes (2004) Crim di Inggris. Kasus tersebut terjadi pada sebuah pertandingan sepak bola di Inggris. Dalam pertandingan tersebut, Mark Barnes melakukan tackling menggunakan dua kaki dari sisi belakang korban bernama Cristopher Bygraves pada Desember 2002, yang menyebabkan Christopher Bygraves mengalami cidera serius di kaki kanannya. Pada 16 Oktober 2003, Crown Court di Canterbury menyatakan bahwa Mark Barnes terbukti melakukan "Grievous bodily harm" sebagaimana diatur pada Section 20 of The Offense Againts The Person Act 1861, yakni tindakan yang mengakibatkan cedera fisik yang sangat serius kepada korban. Hakim menyatakan bahwa terdakwa akan dinyatakan bersalah jika terbukti bahwa apa yang terjadi tidak memikirkan konsekuensi dilakukannya tindakan tersebut, sehingga tidak bisa diterima sebagai suatu legitmate sport dan dapat disamakan dengan penganiayaan yang sangat serius.

Akan tetapi, kasus Rv Barnes tersebut sempat dihadapkan pada keabu-abuan karena the Appeal Court menganggap konsep konsep awal parameter legitimate sport tidak terlalu membantu dalam membuktikan ada tidaknya unsur kriminalitas pada tekel tersebut. Sehingga dalam menyikapi permasalahan tersebut, the Appeal Court juga menyatakan bahwa untuk menentukan tindakan kekerasan tersebut merupakan tindak pidana atau tidak, harus dipahami bahwa di dalam sebuah pertandingan olahraga yang kompetitif, seorang pemain bisa saja melakukan tindakan kekerasan selain dari yang ditentukan dalam peraturan pertandingan mengingat begitu emosionalnya pertandingan tersebut, bahkan jika seandainya tindakan tersebut juga diancam dengan pidana, tidak hanya diancam dengan sanksi disiplin berupa peringatan maupun dikeluarkan dari pertandingan, the Appeal Court masih sulit untuk menentukan secara objektif apakah tindakan kekerasan tersebut dapat dikategorikan sebagai tindak pidana. Karenanya the Appeal Court menetapkan lima kriteria yang dibutuhkan untuk menentukan apakah tindakan kekerasan tersebut diperbolehkan atau tidak untuk dilakukan 
dalam sebuah pertandingan olahraga. ${ }^{27}$ Lima kriteria ini yang kemudian dijadikan sebagai konsep baru dari parameter legitimate sport, kriteria tersebut yakni:

1. Jenis Olahraga yang dipertandingkan

2. Level dari pertandingan tersebut

3. Karakteristik tindakan kekerasan yang digunakan

4. Resiko terjadinya cedera

5. Keadaan pikiran pelaku

Lima kriteria dalam parameter legitimate sport tersebut pada dasarnya bisa menjadi acuan bagi penerapan sanksi pidana ketika terjadi kekerasan yang berada di luar karakteristik dasar permainan sepak bola professional di Indonesia. Adanya parameter tersebut memudahkan penilaian mengenai penentuan tindakan kekerasan yang merupakan bagian dari permainan dan tindakan kekerasan yang bukan bagian dari permainan sepak bola. Penerapan kriteria tersebut tentunya dapat dipandang sebagai peran Negara dalam memberikan perlindungan hukum bagi subjek-subjek yang terkait dalam pertandingan sepak bola. Sehingga, kelak tidak terjadi lagi kejadian kekerasan-kekerasan yang menimpa para pemain dan juga perangkat pertandingan dalam penyelenggaraan sepak bola professional di Indonesia.

Penerapan sanksi pidana di persepakbolaan Indonesia sebenarnya sudah terjadi, akan tetapi masih saja menjadi perdebatan hingga saat ini, karena memang harus disadar bahwa tidak ada paying hukum yang jelas terkait masalah ini. Seperti misalnya kasus yang terjadi di Surakarta yang menghasilkan Putusan Pengadilan Negeri Surakarta Nomor 319/Pid.B/2009/PN.Ska dan Nomor 381/Pid.B/PN.Ska seperti yang telah dijabarkan pada pembahasan sebelumnya. Selain itu, penulis mengambil contoh penerapan sanksi pidana dalam persepakbolaan Indonesia terkait pengatur skor. Penulis memberrikan apresiasi tinggi atas turunnya Negara melalui Kepolisian Republik Indonesia untuk menyelesaikan permasalahan yang selama ini telah mengakar di persepakbolaan Indonesia, yakni terkait dengan pengaturan skor di Indonesia. Terkait intervensi Negara melalui Kepolisian Republik Indonesia dalam menyelesaikan persoalan pengaturan skor ini harus dipandang sebagai langkah positif, terlepas kemudian muncul bayang-bayang sanksi dari FIFA atas adanya intervensi pihak ketiga. Intervensi yang dilakukan Polri ini dapat dikatakan sebagai wujud dari upaya Negara untuk mewujudkan tujuan hukum dari segi kemanfaatan.

${ }^{27}$ Judgement of Court of Appeal (Criminal Appeals Division) Neutral Citation Number [2004] EWCA Crim 3246, Introduction, Point 15. 
Darmodiharjo berpendapat bahwa kemanfaatan diartikan sebagai kebahagiaan (happiness). Jadi baik atau buruknya, adil dan tidaknya suatu hukum, bergantung kepada apakah hukum itu memberikan kebahagiaan kepada manusia atau tidak. ${ }^{28}$ Jeremy Bentham adalah tokoh dari aliran utilitarianisme ini. Pendapat Bentham yang terkenal yaitu "the grratest happiness of the greatest number of people" yaitu kebahagiaan ini selayaknya dapat dirasakan oleh setiap individu, tetapi jika tidak mungkin tercapai (dan pasti tidak mungkin), diupayakan agar kebahagiaan itu dinikmati oleh sebanyak mungkin individu dalam masyarakat (bangsa) tersebut. ${ }^{29}$ Bentham menyatakan bahwa penilaian moral dari suatu perbuatan didasarkan atas hasil atau akibat dari perbuatan itu. Disini Bentham tidak membedakan antara upaya mengejar kebahagiaan individu dengan upaya mengejar kebahagiaan umum, asalkan sebagian besar masyarakat secara pribadi-pribadi sudah merasa bahagia, maka sudah tercapailah tujuan hukum diciptakan. Jadi, titik tekan pendapat dari Bentham disini yaitu kebahagiaan Individu yang menjadi ukuran kebahagiaan. ${ }^{30}$

Pendapat dari Bentham tersebut jika dikaitkan dengan intervensi Negara dalam menyelesaikan kasus pengaturan skor dalam persepakbolaan Indonesia tersebut merupakan usaha Negara untuk mewujudkan "the Greatest happiness of the greatest number of people". Keinginan Negara untuk mewujudkan kebahagiaan sebagian besar orang secara otomatis harus dengan mengorbankan kebahagiaan sebagian kecil orang dapat dilihat dari upaya Negara untuk menjerat sebagian pengurus PSSI yang terlibat skandal pengaturan skor demi menyelamatkan masa depan persepakbolaan Indonesia itu sendiri. Harus dipahami pula bahwa persepakbolaan Indonesia tidak hanya menyangkut pemain, perangkat pertandingan, dan juga penyelenggara sepak bola, melainkan juga melibatkan supporter sepak bola.

Penulis memandang bahwa Indonesia seharusnya mengaca kepada Italia saat membongkar skandal Calciopoli yang terjadi pada rentang 1999-2005. Melalui early warning system (EWS) yang diterapkan oleh FIFA yang bekerjasama dengan Interpol untuk memonitor pertandingan sepak bola, mengidentifikasi beragam tindakan di luar aturan di pasar taruhan sepak bola dan potensi manipulasi skor pertandingan, skandal Calciopoli terbongkar pada 2006. Hukuman yang dikenakan kepada klub dan individu yang terlibat pengaturan skor sungguh berat. Klub sekelas Juventus harus degradasi ke Serie B setelah

${ }^{28}$ Zainal B. Septiansyah \& Muhammad, (2018), Konsepsi Utilitarianisme dalam Filsafat Hukum dan Implementasinya di Indonesia Ghalib, Ijtihad: Jurnal Hukum Islam dan Pranata Sosial, Volume 34, Nomor 1, hlm. 27-34.

\footnotetext{
${ }^{29}$ Ibid.

30 Astim Riyanto,(2010), Filsafat Hukum, Bandung: Yapemdo, hlm. 260
} 
direktur umumnya, Luciano Moggi, terbukti melakukan percakapan telepon untuk memengaruhi pejabat Federasi Sepak Bola Italia (FIGC) dalam penunjukan wasit.

PSSI sebagai induk dari sepak bola Indonesia bisa saja meniru apa yang telah dilakukan oleh FIFA dan FIGC tersebut. PSSI bisa berkolaborasi dengan Kepolisian Republik Indonesia untuk memberantas pengaturan skor. Kolaborasi antara keduanya bisa dengan cara menerapkan sistem yang sama yang diterapkan oleh FIFA dan FIGC sebagai tindakan preventif untuk menanggulangi pengaturan skor. Selain itu, sebagai tindakan represif nantinya sanksi yang diterapkan kepada oknum pengaturan skor juga tidak hanya sebatas sanksi disiplin, melainkan juga dengan menggunakan sanksi pidana. Hal tersebut tentunya diharapkan dapat menimbulkan efek jera bagi pelaku.

Kolaborasi antara Negara dan juga PSSI jika dilakukan dengan baik tentunya akan menciptakan penyelenggaraan sepak bola di Indonesia yang lebih baik. Kolaborasi yang berupa pembagian kewenangan tersebut diharapkan nantinya dapat menghindari benturanbenturan yang selama ini terjadi. Pembagian kewenangan tersebut seperti misalnya memberikan kewenangan penuh terhadap PSSI dalam melakukan penyelenggaraan dan pengelolaan sepak bola di Indonesia. Akan tetapi, perlu digaris bawahi terkait pemisahan kewenangan tersebut harus tercantum dalam peraturan perundang-undangan dalam sistem hukum Indonesia. Sehingga, di kemudian hari tidak terjadi konflik-konflik yang terjadi seperti selama ini yang berkaitan dengan penyelenggaraan sepak bola di Indonesia karena dianggap baik Negara maupun PSSI mempunyai kewenangan yang sama.

Pembagian kewenangan juga perlu dilakukan dalam aspek kepidanaan. Seperti yang telah disampaikan di atas, sanksi pidana perlu diterapkan berkaitan dengan kekerasan yang berada di luar karakteristik dari sepak bola. Penerapan sanksi pidana terhadap kekerasan di luar karakteristik dari sepak bola di rasa perlu untuk memberikan perlindungan hukum bagi subjek-subjek yang sering menjadi korban kekerasan di dalam pertandingan sepak bola di Indonesia. Penerapan pidana tersebut nantinya juga diharapkan dapat menciptakan sepak bola Indonesia yang jauh dari konflik-konflik yang disebabkan oleh rivalitas dalam pertandingan.

Negara dan PSSI juga perlu berkolaborasi dalam pemberantasan mafia pengaturan skor. Terkait hal ini, baik Negara dan PSSI bisa saling bekerjasama untuk sama-sama berkomitmen memberantas praktek pengaturan skor. PSSI sebagai induk sepak bola Indonesia bisa mencontoh FIFA sebagai induk persepakbolaan dunia yang menggandeng Interpol untuk memberantas praktek pengaturan skor. Sehingga, penulis melihat bahwa PSSI pun bisa 
menggandeng Negara melalui Kepolisian Republik Indonesia dalam memberantas praktek pengaturan skor di Indonesia yang sudah dinilai sebagai penyakit yang kronis.

Sempitnya jangkauan PSSI yang hanya bisa menghukum subjek-subjek dalam sepak bola dirasa menjadi halangan tersendiri ketika ingin menjerat para mafia pengaturan skor. Selain sempitnya jangkauan, konsep sanksi yang diberikan oleh PSSI sendiri dirasa tidak menimbulkan efek jera. Sehingga, penulis merasa perlu adanya penerapan sanksi pidana untuk memberantas permasalahan mafia pengaturan skor. Sanksi pidana ini dapat dicantumkan ke dalam peraturan perundang-undangan yang mengatur masalah pengaturan skor dalam sepak bola. Diterapkannya sanksi pidana ini nantinya diharapkan bisa benar-benar memberantas mafia pengaturan skor, yang pada akhirnya dapat memicu iklim persepakbolaan Indonesia yang sehat dan bersih.

\section{PENUTUP}

Statuta PSSI Sebagai bagian dari kepanjangan Statuta FIFA merupakan peraturan yang mengatur secara keseluruhan mengenai tata kelola, pelaksanaan, dan penyelesaian sengketa terkait jalannya sepak bola professional di Indonesia. Statuta PSSI tersebut dapat dikatakan termasuk Lex Sportiva yang terdapat di Indonesia. Akan tetapi, kaidah-kaidah yang terdapat dalam statuta PSSI sebagai Lex Sportiva tersebut tetap harus tunduk terhadap segala kaidah yang terdapat dalam sistem hukum di Indonesia. Hal tersebut didasari oleh kedudukan statuta PSSI yang hanya sebagai rule of the game dan bukan sebagai rule of the law seperti yang tercantum dalam Pasal 7 Ayat (1) Undang-Undang Nomor 12 tahun 2011 tentang Pembentukan Peraturan Perundang-undangan yang berisi jenis-jenis peraturan perundangundangan di Indonesia. Selain itu, bukan merupakan produk hukum yang dihasilkan oleh Presiden maupun DPR. Sehingga, meski diakui sebagai Lex Sportiva, kedudukan dari statuta PSSI tidak bisa serta merta mengesampingkan kedudukan hukum nasional.

Pengaturan ke depan terkait dengan kedudukan statuta PSSI sebagai Lex Sportiva dalam Negara hukum Indonesia dapat dilakukan dengan cara memberikan pembagian kewenangan antara Negara dengan PSSI. Pembagian kewenangan tersebut bisa dilakukan dengan cara memberikan kewenangan penuh kepada PSSI untuk menyelenggarakan dan mengelola persepakbolaan Indonesia. Selain itu, penerapan sanksi pidana terkait penganiayaan d luar karakteristik permainan sepak bola dan kolaborasi antara PSSI dan Kepolisian Republik Indonesia terkait pengaturan skor juga dirasa perlu untuk menumbuhkan iklim persepakbolaan Indonesia yang sehat dan bersih. Baik pembagian kewenangan dan 
penerapan sanksi pidana tersebut harus tercantum dalam peraturan perundang-perundang yang sesuai dengan jenis peraturan-perundang-undangan yang ada di Indonesia, sehingga memberi kedudukan pasti statuta PSSI di mata hukum nasional. 


\section{DAFTAR PUSTAKA}

\section{Buku}

G. Teubner (Ed.), (1997), Global Law Without a State, Dartmouth: Andover.

Hinca IP Pandjaitan XII, (2011), Kedaulatan Negara vs Kedaulatan FIFA, Jakarta: Gramedia Pustaka Utama.

Mark James, (2010), Sports Law, Hampshire: Palgrave Macmilan.

Mikanda Rahmani, (2014). Buku Super Lengkap Olahraga. Jakarta: Dunia Cerdas.

P.A.F. Lamintang, (1997) Dasar-Dasar Hukum Pidana Indonesia, Bandung: Citra Aditya Bhakti.

Astim Riyanto, (2010), Filsafat Hukum, Bandung: Yapemdo.

\section{Peraturan Perundang-Undangan}

Undang-Undang Republik Indonesia Nomor 12 Tahun 2011 tentang Pembentukan Peraturan Perundang-Undangan sebagaimana diubah dengan Undang-Undang Republik Indonesia Nomor 15 Tahun 2019.

Judgement of Court of Appeal (Criminal Appeals Division) Neutral Citation Number [2004] EWCA Crim 3246

\section{Jurnal}

Anderson, (2008), "No License fot Thuggery: Violence, sport, and criminal law", Criminal Law Review, Volume 7 Nomor 1.

Angelica Maureen Taroreh, (2020), "Izin Pihak Korban Sebagai Dasar Peniadaan Pidana Di Luar KUHP”, Jurnal Lex Crimen, Volume 9 Nomor 3.

Bayan Ardana Wikarta \& Muzni Rofik, (2020) "Latihan Small Sided Games Dalam Ketepatan Passing Pada Ekstrakurikuler Sepak Bola”, Jurnal Sportif Pendidikan Jasmani, Kesehatan Dan Rekreasi, Volume 5 Nomor 2.

Bivitri Susanti, (2017), "Menyoal Jenis Dan Hierarki Peraturan Perundang-Undangan Di Indonesia", Jurnal Jentera, Volume 1 Nomor 2.

Depri Liber Sonata, (2014), "Metode Penelitian Hukum Normatif dan Empiris", Fiat Justicia Jurnal Ilmu Hukum, Volume 8 Nomor 1.

Foster K., (2019), “Global Sports Law Revisited”, Entertainment and Sports Law Journal, 17: 4. 
Aruan, P., Bintang, H., Sirait, N. N., \& Leviza, J., (2014), “Berlakunya Statuta Fédération Internationale De Football Association (Fifa) Dikaitkan Dengan Kedaulatan Negara (Studi Kasus Dualisme Persatuan Sepakbola Seluruh Indonesia (PSSI))", Journal of USU International Law, Volume 2 Nomor 1.

Jevon Andriani Djayadilaga \& Arinto Nugroho, (2021), "Perlindungan Hukum Terhadap Pemain Sepakbola Profesional Di Indonesia Yang Mengalami Keterlambatan Dalam Pembayaran Upah", Novum: Jurnal Hukum, Volume 8 Nomor 4.

Muhammad Fadli, (2018), "Pembentukan Undang-Undang Yang Mengikuti Perkembangan Masyarakat", Jurnal Legislasi Indonesia, Volume 15 Nomor 1.

Pedomanta Keliat dan Boby Helmi, (2018), "Upaya Meningkatkan Hasil Belajar Shooting Pada Permainan Sepak Bola Melalui Gaya Mengajar Inklusi Pada Siswa Kelas Viii Smp Negeri 4 Percut Sei Tuan”, Jurnal Ilmiah STOK Bina Guna Medan, Volume 6 Nomor 2.

Rusnan, (2014), "Konsep Negara Hukum Dalam Hubungan Kekuasaan Freiss Ermerssen Dalam Welfare State", Jurnal IUS, Volume II Nomor 4.

Yati Nurhayati, (2013), "Perdebatan Metode Normatif dengan Metode Empirik Dalam Penelitian Ilmu Hukum Ditinjau Dari Karakter, Fungsi dan Tujuan Ilmu Hukum”, Jurnal Al Adl, Volume 5 Nomor 10.

Zainal B. Septiansyah \& Muhammad, (2018), "Konsepsi Utilitarianisme dalam Filsafat Hukum dan Implementasinya di Indonesia Ghalib", Ijtihad: Jurnal Hukum Islam dan Pranata Sosial, Volume 34 Nomor 1.

\section{Internet}

Ken

Foster, Is $\quad$ There
https://www.researchgate.net/publication/251276514 Is

